\title{
PRODUCING GOOD STORIES IN ENGLISH AS A FOREIGN LANGUAGE: ANALYSIS OF THE KURDISH EFL LEARNERS' ORAL "FROG STORY" NARRATIVES
}

\author{
HALlAT RAJAB EBRAHIM \\ Dept. of English, College Of Languages, University of Duhok, Kurdistan Region-Iraq
}

(Received: April 13, 2020; Accepted for Publication: August 19, 2020)

\begin{abstract}
ABSRACT
By focusing on the structural elements particularly the evaluative devices by (Labov \& Waletzky, 1967) and (Peterson \& McCabe, 1991), this study examined how the Kurdish participants' narrative discourse deviate from the target language discourse, and how this deviation is explained in line with the cultural discourse strategies in both types of discourse (Kurdish and English). This study analyzed the frog narratives told by the EFL Kurdish participants (in Kurdish and English) and the American speakers with special attention on the narrative length, narrative structure and evaluative devices. The findings from the T-test and MANOVA statistics revealed cross-cultural patterns of differences between the narratives told by the Kurdish and the American speakers. Generally, the narratives told by the American participants were longer than those told by the Kurdish participants in both Kurdish and English. The American speakers elicited narratives with frequent evaluation. Conversely, the Kurdish participants constructed narratives with higher number of durative (descriptive) clauses, orientation and repetition.
\end{abstract}

KEY WORDS: Evaluative devices, Narrative discourse, Kurdish participants, Target Language

\section{INTRODUCTION}

A $s$ a Kurdish EFL (English as a foreign language) lecturer, I first become interested in investigating oral narratives related to cultural groups because my students produced narratives in the target language conversations which encountered problems at the discourse level. When constructing their narratives, my students used an interlanguage. They made a number of strategical and lexical errors in their English language conversational narratives. One possible way to explore relative to my students narratives told in English language is "language transfer". It would seem that there is the effect of the first mother tongue language transference on the second language narratives told in English by Kurdish students. The term transfer is used to indicate the passing on of the forms and meanings of the native language and culture to the second language and culture (Selinker\&Gass, 1991, p.1). Culture plays an important role in second language acquisition. Kang (2003: 123) argued that acquiring the competence of a second language does not merely require the second language learners to internalize its grammar and vocabulary but they need to master its discourse norms and rules too. To put it another way, second language learners must realize the "real language, used by real people in real contexts both in written and spoken modes, rather than artificially created sentences and texts" (Akpinar, 2012:256). This is considered as an obstacle for the EFL learners as they probably fail to meet the cultural norms and strategies of the target language. Although advanced Kurdish EFL learners have seldom committed mistakes on the sentence level, and commit grammatical mistakes, they are unable to produce a longer discourse as stories which sound natural and easy to native speakers of English. This study is not concerned to discourse errors and mistakes. Thus it is important to explore what Kurdish EFL learners are missing in terms of discourse styles in English, in order to help them to be more competent learners in the target language in this case English language and culture. In this respect, a narrative is a crucial tool that index's the learners' communicative competence and underpins discourse problems, particularly since narrative reflects social values and cultural habits that may vary within different cultures (Mc Cabe \&Peterson, 1991). Since the Kurdish language is 
different from the English language in terms of its grammar system, vocabulary, style, cultural norms and discourse strategies, one can predict that some Kurdish EFL learners will encounter difficulty in producing narrative discourse in English language. So far no study has investigated how such learners' narrative production differs from the native speakers' narratives. The aim of this study is to investigate how Kurdish learners' oral narrative discourse differs from that of English and their Kurdish cultural background may be evident in their performance in English.

\section{CULTURE SPECIFITY OF NARRATIVE DISCOURSE}

The importance of narrative discourse in investigating the learners' communicative competence is long been emphasized by some researchers and among them are (Sage \&Wilde, 2007). They suggest that it is hard for second language children "to make the shift between their informal language to a formal mode in which they are able to use narrative skills to both process large quantities of talk and produce a coherent response and thereby access the curriculum" (p.681). Children acquire narrative discourse forms in their early stages (McCabe \&Peterson, 1991) constructing a basic type of discourse that is considered differently in different cultures (Bruner, 1990). Research on parent-child talk and mother-child dyads emphasized on the ways parents socializing their children into memberships in their culture by modeling the narrative constructs that it values (Blum-Kulka, 1993; Melzi, 2000; Mullen\&Yi 1995; and Peterson\&McCabe, 1992). Miami \&McCabe (1995) examined mothers and children forms of narratives of Japanese and English speaking and found that their narrative styles are different culturally. Japanese mothers requested proportionally less description from their children, gave less evaluation and displayed more verbal attention to children than did the American mothers. In their study on the comparison between the Korean and Caucasian where adults engaged children in a process of "co-constructing memories", Mullen \&Yi (1995), showed differences in the narrative discourse produced by both groups where the Caucasian dyads engaged in talk about past events more frequently than the Korean dyads. Also there were content differences. Caucasian adults report earlier childhood memories than
Asians. Cultural differences come to the fore. Bllum-Kulka (1993) explored the cultural diversity in the dinner-table conversation narrative events of the middle -class JewishAmerican and Israeli families. American families locate the talk outside the home close in time. Israeli families told stories more distant in time but close to home. Israeli families shared stories that were circular around the family 'us' as protagonist. However, American families claimed access to story ownership through familiarity celebrating monologic performances but Israelis ownership was achievable through polyphonic participation in the telling. Examining the cultural variations in the narrative elicitation styles between Spanish-speaking central Americans and English speaking European American, Melzi (2000) indicated that central and European American mothers emphasized different aspects of narrative interaction. Central American elicitation style put greater focus on conversational narrative aspect, whereas European American mothers' style focused more on organizational narrative aspects of interaction. All these research show that "children are socialized by older members of the culture to acquire the appropriate norms and language forms needed to produce culturally appropriate narrative discourse" (Kang, 2003, p.129)

\section{CROSS-CULTURAL STUDIES OF NARRATIVES}

Studies have shown cross-cultural differences in the narrative styles in terms of evaluation function and narrative structure (Labov\&Waletzky, 1969). Evaluation function of narrative has been clarified by Labov (1972) as the emotional assessment and attitudes conveyed by the narrator towards the events in the narrative. This attitude reveals the narrator's feelings and thoughts towards the events and the participants through a variety of linguistics strategies such as repetition, intensifiers (qualifiers and quantifiers), adverbs, onomatopoeia, reported speech and thorough the narrator's explicit (external) evaluation comments (e.g: I am very serious) (Labov, 1972). Generally, cross-cultural studies on the elicitation of evaluative devices in the narratives suggested that the differences lie in the amount of the inclusion of the evaluative devices in narratives across different cultures and languages. For instance, in their study, Kuntay 
\&Nakamura (1993) showed that the Turkish and Japanese narrators did not use explicit evaluative comments, which contrasts with the findings of Bamberg \& DamradFrye (1991) where the native Americans speakers used frequent evaluative devices.

The other narrative dimension that underpins cross-cultural differences is the narrative structure Labov (1972). A number of studies have shown variation in narrative structure cross-culturally, such as the studies on the structure of the narratives by: Japanese and English speakers in Miami\&McCabe (1995), Taiwanese and British speakers in Chang (2008), Eurepean-American in Peterson \&McCabe (1993), African-American in Heath (1983), Venezuelan in Shiro (1998) and Andean Spanish and Ameican speakers in Uccelli (2008). Uccelli (2008) examined Andean-Spanich speaking children's temporality in the construction of narratives. The Andean Spanish speaking children's narratives showed functional deviation from the time line of the real events and included independed stories connected within the boundaries of the single narrative, unlike the American children whose narratives were sequentially organized and a no ne to one narrative story scheme.

Overall, all the aforementioned studies foreground cross-cultural differences in the narrative style and reveal particular discourse style that is valued in each culture and language. Thus studying narrative discourse gives a rich view on the particular discourse styles preferred in a particular culture and the narrators' discourse competence in a particular language and culture. Thus narrative discourse is an essential tool to study foreign language learners' knowledge about the socio-cultural norms and preferred style of the discourse in the target language and culture. Yet, less attention is given to the study of the foreign language learners' narrative competence in terms of utilization of it in specific cultural strategies.

\section{STUDIES IN FOREIGN LANGUAGE NARRATIVES}

Studies on the foreign and second language learners' narratives have shown the deviant forms of narrative discourse produced by L2 learners from the target language and have shown the effect of language transfer on their narrative discourse in the target language. Chang (2008) in her cross-cultural study on the similarity and differences in the Mandarin and English Frog narratives found that there are some cultural variance between the narratives produced by Taiwanese and British English speakers. In his comparison of the structures of the Japanese and English narratives told by the EFL American learners of Japanese, Maeno (1996) found that the participants' awareness of the preferred discourse style in English of Japanese enabled them to elicit more actionoriented narratives in English and more outcome-oriented narratives in Japanese. Ordo'n $n^{\sim}$ ez (2000) studied the oral narratives produced by the Spanish-English monolinguals and Spanish-English bilingual adolescents adopting the Frog story prompt. Ordonez found similarities in various narrative features in bilinguals' skills in Spanish and English and concluded that the first language helps the acquisition of the target language. In a similar vein Akinci (2001) found few differences in the use of the narrative structural components in the narratives told by Turkish-French bilingual children's oral frog story in the two languages. Peterson (2001) in contrast, found that Spanish English bilingual children's oral frog narratives included fewer mental verbs mention in either language than monolingual Spanish or English speaking children. Kang (2003) compared the Frog narratives told by the EFL Korean speakers and the American native speakers and indicated variations in the narrative discourse of the two groups. It was found that the American speakers elicited more amounts of explicit evaluation than the Korean speakers.

The studies mentioned above showed similarities and differences between the narrative style preferred in different languages including Turkish, English, Spanish, Mandarin and Korean. However, to the best of the researcher's knowledge no study yet has explored the narratives told by Kurdish speakers' oral frog story narrative discourse. Further, there is no existing literature on the Kurdish EFL learner's narrative discourse in English, although it is highly predictable that they would encounter difficulties, as their native language (Kurdish) is culturally different from English. It is so likely that the EFL Kurdish learners will repeat the information in their Kurdish and English narratives more than the native English speakers. This will lead the Kurdish participants to elicit oral frog story English narratives that deviate from the native speakers' narrative discourse. 


\section{THE IMPORTANCE OF STUDYING FOREIGN LANGUAGE LEARNERS' NARRATIVES}

Research on first language narrative area has suggested that the oral narratives are important components for pragmatic skills in the target language (Gottman\&Parker, 1986; Norick, 2001). Therefore, by examining foreign language learners' oral narrative discourse, we can underpin the areas of difficulty they may experience in the target language pragmatic discourse (Kang, 2003). Studies have also shown that the relationship between the oral narrative skills and other language skills such as comprehension for first language acquirer (Beach, 1995; Cain\& Oakhill, 1996; Griffin, 1998;Hemphill1999; Klecan-Aker \& Garaway, 1997) and second/foreign language learners (Bensoussan, 1990 and Horbia,1990). For example, Cain \& Oakhill (1996) examined how children's reading comprehension skill is related to their ability to tell stories based on picture prompts and showed that the children's ability to tell good stories is based on their knowledge of the story structure seem to play an important role in reading comprehension ability. Studies also have shown that cultural-specific background knowledge and inferences language upon the comprehension of second language written text (Kang, 1992).

\section{RESEARCH QUESTIONS}

1. What cultural differences can be found between American native English speakers' English and native Kurdish speakers' Kurdish oral narrative discourse?

2. How are Kurdish native speakers' oral narratives in EFL (English as a foreign) different from the target norms that may be due to culturally specific narrative styles?

3 . Are any specifically Kurdish cultural strategies evident in Kurdish learners' English oral narratives?

\section{METHODOLOGY}

\subsection{Participants}

In the current study, a sample of 36 oral frog narratives is analyzed. Twelve stories produced by twenty-year -old English native speakers (Americans) were collected by Virginia Marchman and Dan Slobin that are available for public use through the Child Language Data
Exchange System (CHILDES). The other 24 frog stories (12 in Kurdish and 12 in English) were produced by Kurdish University students studying in the Department of English (year four)/ College of Languages/ University of Duhok, within the age range from 20-26 years old. The rationale for choosing university students studying in English Department (year four) goes back to the fact that they have acquired most of their English language skills in that they have received eight years of formal compulsory EFL education (primary, secondary and high school) and 3 years of college in the Department of English for the academic year (2019-2020).

\subsection{Procedures}

The oral narratives in this study were elicited using the wordless picture book, "Frog, Where are you?" By Mercer Mayer (1969).This book was chosen to gain asymmetrical data that are reliable for comparison. This use of such prompt was particularly important for the participants recruited in this study as there has been no consensus on what the Kurdish adult narrative competence look like. By using Frog, Where are you? a widely used picture prompt by researchers in the narrative domain (Bamberg, 1987; Berman \& Slobin, 1994 and Chang, 2008), the researcher intended to investigate Kurdish narratives characteristics which have been under scrutinized from this perspective before, in comparison to the American English native speakers.

\subsection{Transcription and categories of analysis}

To change the raw data to concrete material, the audiotaped of the Kurdish and English narratives were transcribed and coded into Excel. Each narrative was divided into clauses. As Berman and Slobin (1994) suggested, the clause is "more linguistically structured than the behavioral unit of an 'utterance' but less determined by syntactic criteria than a 'sentence' (p. 26). A clause is defined as "any unit that contains a unified predicate. By unified is meant a predicate that expresses a single situation (activity, event, or state). Predicates include finite and nonfinite verbs as well as predicate adjectives"(p. 660). This definition of clause is also applicable to Kurdish, so both Kurdish and English data were coded accordingly. After the analysis and coding of the narratives in the clause level, they are analyzed for the following features:

Narrative length: Excel was used to measure the length of the narratives (the number of clauses). 
Narrative structure: It was long stated previously by researchers that a 'good' story comprises the following ((Labov \& Waletzky, 1967; Peterson \& McCabe, 1983):

Orientation: Clauses that described the context of the narrative (place, time and participants) were coded as orientation.

Appendages: Clauses that served to signal the beginning (abstract) or the end of the narrative that summarized the story were coded as appendages.

Events: Events and character actions that marked the plot of the story were coded as events.

Duratives: Clauses which represented descriptive information related to who and what was involved in the events and where and when the events took place.
Evaluations: Clauses that describe the narrator's point of view, including references to the mental state of characters, and narrators' individual stylistic ways of presenting information were coded as evaluations.

I coded evaluation at two different levels in this research: one was under the narrative structure stage which was called the explicit evaluation (Labov, 1972) where the narrator stops the flow of the narrative and comment clearly on the events (e.g.: I am sad). There was also a separate evaluation stage which included any evaluative devices spreaded in any part of clauses with other narrative functions as well. Using an adaptation of Peterson and McCabe's (1983) classification, categories of separate evaluation stage included the ones in Table 1 bellow.

Table (1): Evaluative devices adapted from McCabe and Peterson's (1983) classification

\begin{tabular}{ll}
\hline Expressions of emotions & the boy is sad \\
\hline Mental state of the characters (i.e., expressions of cognitions or character intentions) & $\begin{array}{l}\text { the boy thought that ..." } \\
\text { "she decided to...", etc. }\end{array}$ \\
\hline Intensifiers & He was very happy. \\
\hline Expressions of defeat of expectation/Negatives & ..but there was no hope. \\
\hline Repetitions & He screamed again and again. \\
\hline Hedges & He was kind of confused. \\
\hline Charect and indirect reported speech & "Where are you, frog?", He asked the dog \\
\hline if he saw the frog" \\
\hline
\end{tabular}

In terms of coding, the clause "he was very happy" was coded as an explicit evaluation in the narrative structure stage and also the evaluative devices like "very" was coded as an intensifier and ("happy") as an expression of emotion in the evaluation stage. On the other hand, "he ran fast" was coded as an event for narrative structure but was also given credit for use of an adverb ("fast") in the evaluation stage.

\subsection{Reliability of the coding}

In order to ensure the reliability of the coding, two sets of narratives from each group (i.e. two in English and two in Kurdish from the stories told by the EFL learners and two English narratives told by American native speakers) were selected randomly and given to two EFL lecturers specialized in English language to code these narratives for the structural and evaluative devices. The results of their coding were in harmony with that of the researcher.

\section{RESULTS}

\subsection{Comparing native English speakers' and Kurdish first language narratives: \\ a. Narrative Length}

Table 2 below presents a comparison between the means and standard deviations for the narrative length (number of clauses) in the English native speakers' (NES) narratives and the EFL Kurdish participants Kurdish narratives (EFLKK). T-test was used to conduct the frequency of the variants. As Table 2 shows there is a significant difference between the narrative length of both groups $(\mathrm{t}=6.905, \mathrm{p}=p<$ $.01)$. The mean for the native English speakers' narrative clauses is 105.4286 while for the EFL 
Kurdish speakers narrative clauses is 104.5000 . This means that the Kurdish speakers told shorter narratives than the English speakers. This finding is in line with that of Kang's (2003) where the Korean speakers told shorter stories in Korean than the American speakers.

Table (2): Means and standard deviations for narrative length variables: Comparing the native English speakers' and the EFL Kurds' Kurdish narratives.

\begin{tabular}{llll} 
NES & \multicolumn{3}{c}{ EFLKK } \\
$(N=14)$ & \multicolumn{1}{c}{$(N=14)$} & Mean & \\
\cline { 2 - 4 } & Mean & $(S D)$ & \\
\hline Clause & $(S D)$ & 104.5000 & $6.905^{* *}$ \\
& 105.4286 & $(191.7164)$ & \\
\hline
\end{tabular}

$\tilde{p}<.10 * p<.05 * * p<.01 * * * p<.001$

\section{b. Narrative structure:}

Table (3): Means and standard deviations for narrative structure variables, comparing the native English speakers' English narratives and the EFL Kurds' Kurdish narratives

\begin{tabular}{|c|c|c|c|}
\hline & $\begin{array}{c}\text { NES } \\
(N=14)\end{array}$ & $\begin{array}{l}\text { EFLKK } \\
\qquad(N=14)\end{array}$ & $F$ \\
\hline $\begin{array}{l}\text { Mean } \\
(S D) \\
\end{array}$ & $\begin{array}{c}\text { Mean } \\
(S D)\end{array}$ & & \\
\hline \multirow[t]{2}{*}{ Orientation } & 39.06 & 44.42 & $20.34^{\star *}$ \\
\hline & (39.68) & (26.06) & \\
\hline \multirow[t]{2}{*}{ Appendages } & 36.06 & 38.92 & $3.3^{\sim}$ \\
\hline & (43.92) & $(33.84)$ & \\
\hline \multirow[t]{2}{*}{ Event } & 447.56 & 328.42 & $1.88^{\sim}$ \\
\hline & $(538.02)$ & $(375.57)$ & \\
\hline \multirow[t]{2}{*}{ Duratives } & 76.56 & 153.42 & $8.21^{*}$ \\
\hline & (13.34) & $(128.08)$ & \\
\hline \multirow[t]{2}{*}{ Evaluation } & 36.56 & 34.42 & $39.33^{* * *}$ \\
\hline & $(43.22)$ & $(40.20)$ & \\
\hline \multicolumn{3}{|c|}{ MANOVA Wilks' Lambda } & $25.542^{* *}$ \\
\hline
\end{tabular}

$\tilde{p}<.10 * p<.05 * * p<.01 * * * p<.001$

Table 3 presents the means and the standard deviations for five structural elements (orientation, appendages, events, duratives and evaluation) in the native English speakers' and the EFL Kurds' Kurdish narratives. The frequencies of the structural narrative elements were calculated by using MANOVA multivariate analysis. The statistics in Table 3 suggest that there are significant differences in the two groups of narratives for three structural elements $(\mathrm{F}=25.542, \mathrm{p}<.01)$. The statistical analysis showed that the EFLKK significantly included more orientation 44.42, than the NES $39.06(\mathrm{~F}=20.34, p<.01)$. Durative clauses also are used more frequently by EFLKK 153.42 than the NES $76.56(\mathrm{~F}=8.21, p<.05)$. However, the NES contained more explicit evaluation 36.56 than the EFLKK 34.42 ( $\mathrm{F}=39.33, \mathrm{p}<.001)$. This finding supports Kang's (2003) results where she found that the American participants elicited more explicit evaluation in their narratives than did the Korean speakers.

\section{c. Evaluative devices:}


Table 4: Means and standard deviations for the evaluative variables, comparing the native English speakers' English narratives and the EFL Kurds' Kurdish narratives

\begin{tabular}{|c|c|c|c|}
\hline & $\begin{array}{l}\text { NES } \\
(N=14)\end{array}$ & $\begin{array}{l}\text { EFLKK } \\
\qquad(N=14)\end{array}$ & $F$ \\
\hline $\begin{array}{l}\text { Mean } \\
(S D)\end{array}$ & $\begin{array}{c}\text { Mean } \\
(S D)\end{array}$ & & \\
\hline \multirow[t]{2}{*}{ Emotion } & 50.56 & 42.42 & $35.65^{* *}$ \\
\hline & (23.42) & (28.89) & \\
\hline \multirow[t]{2}{*}{ Mental } & 38.56 & 33.42 & $5.77^{*}$ \\
\hline & $(40.391)$ & $(41.61)$ & \\
\hline \multirow[t]{2}{*}{ Intensifiers } & 61.06 & 47.92 & 1.02 \\
\hline & (8.572) & (21.11) & \\
\hline \multirow[t]{2}{*}{ Defeat/negative } & 54.06 & 50.92 & $66.09^{\star * *}$ \\
\hline & (18.47) & (16.86) & \\
\hline \multirow[t]{2}{*}{ Repetition } & 166.56 & 262.92 & $2.254^{*}$ \\
\hline & (140.62) & (282.94) & \\
\hline \multirow[t]{2}{*}{ Hedges } & 34.56 & 31.42 & $52.30^{\star \star *}$ \\
\hline & (46.04) & (44.44) & \\
\hline \multirow[t]{2}{*}{ Reported speech } & 35.06 & 31.92 & 4.3 \\
\hline & (45.34) & (31.92) & \\
\hline \multirow[t]{2}{*}{ Delineation } & 64.56 & 42.92 & $54.4^{\star * *}$ \\
\hline & (3.62) & (28.18) & \\
\hline \multirow[t]{2}{*}{ Adverbs } & 67.06 & 32.42 & $92.22^{* * *}$ \\
\hline & $(.08)$ & (43.03) & \\
\hline
\end{tabular}

MANOVA Wilks' Lambda $85.56^{\star \star *}$

$\tilde{p}<.10 * p<.05 * * p<.01 * * * p<.001$

Table 4 displays the results of the means and standard deviations of the evaluative devices in the English native speakers' and the EFL Kurds' Kurdish narratives. The measurements of nine evaluative devices namely (emotions, mental, intensifies, negatives, delineation, repetitions, hedges, reported speech, delineation and adverbs) were conducted by using the MANOVA analysis. The multivariate analysis in Table 4 again shows a significant difference in the use of evaluative devices in NES and EFLKK $(\mathrm{F}=85.56, \mathrm{p}<.001)$. The MANOVA analysis indicates significant differences in the narratives told by the NES and EFLKK in terms of some evaluative devices such as (emotions, mental, negatives, hedges, delineation, repetition and adverbs). EFLKK used more frequent amounts of repetition in their Kurdish narratives than the American speakers. However, NES are more likely to use (emotions, mental, negatives, hedges, delineation and adverbs) more than the EFLKK. This finding supports that of Bamberg \& Damrad Frye's (1991) findings where they discovered that the native American speakers elicited frequent evaluative devices in their stories. In the meantime, reported speech and intensifiers do not show any significant differences between the two groups of narratives

8.2 Comparing native English speakers' and EFL Kurds' English language narratives: a. Narrative length:

Table 5: Means and standard deviations for narrative length variables, comparing the native English speakers' English narratives (NES) and the EFL Kurds' English narratives (EFLKE)

\begin{tabular}{llll} 
& NES & \multicolumn{2}{c}{ EFLKE } \\
$(N=14)$ & & $(N=14)$ & \multicolumn{1}{c}{ Mean } \\
& Mean & $(S D)$ & \\
\cline { 2 - 4 } & $(S D)$ & 104.9284 & $6.892^{* *}$ \\
\hline Clause & 105.4286 & $(170.6090)$ & \\
& $(218.8454)$ &
\end{tabular}

$\tilde{\sim}<<.10 * p<.05 * * p<.01 * * * p<.001$ 
Table 5 shows the means and standard deviations of the narrative length in the native English speakers and the Kurds' narratives in English. The measurements were conducted by using a T-test analysis. The statistics in Table 5 highlights a significant difference between the two groups of narratives $(t=6.892, p<.01)$. NES included more narratives than the EFLKE (105.4286 and 104.9284) respectively.

\section{b. Narrative structure}

Table 6: Means and standard deviations for narrative structure variables, comparing the native English speakers' and the EFL Kurds' English narratives

\begin{tabular}{|c|c|c|c|}
\hline & $\begin{array}{c}\text { NES } \\
(N=14)\end{array}$ & $\begin{array}{l}\text { EFLKE } \\
\quad(N=14)\end{array}$ & $F$ \\
\hline $\begin{array}{l}\text { Mean } \\
(S D)\end{array}$ & $\begin{array}{c}\text { Mean } \\
(S D)\end{array}$ & & \\
\hline \multirow[t]{2}{*}{ Orientation } & 39.06 & 51.17 & $5.6^{*}$ \\
\hline & (39.68) & (11.56) & \\
\hline \multirow[t]{2}{*}{ Appendages } & 36.06 & 32.67 & $2.02^{\sim}$ \\
\hline & (43.92) & (37.72) & \\
\hline \multirow[t]{2}{*}{ Event } & 447.56 & 297.67 & $6.45^{\star}$ \\
\hline & $(538.02)$ & (337.03) & \\
\hline \multirow[t]{2}{*}{ Duratives } & 76.56 & 141.17 & $15.23^{\star \star}$ \\
\hline & (13.34) & (115.71) & \\
\hline \multirow[t]{2}{*}{ Evaluation } & 36.56 & 32.17 & $34.9^{*}$ \\
\hline & (43.22) & (38.43) & \\
\hline \multicolumn{3}{|c|}{ MANOVA Wilks' Lambda } & $19.98^{* \star}$ \\
\hline
\end{tabular}

Table 6 presents the statistical results of the narrative structure in the English native speakers' and the EFL Kurdish speakers' English narratives. The frequencies for the five structural elements were measured by the MANOVA analysis. Five structural components are shown to be significantly different in both groups of narratives $(\mathrm{F}=19.98, p<.01)$. Similar to EFLKK, EFLKE included more instances of orientation 51.17 and durative (descriptive) clauses 141.17 than NES 39.06 and76.56 $(\mathrm{F}=5.6$, $p<.05)(\mathrm{F}=15.23, p<.01)$ respectively. This result contradicts with Miami \& McCabe's (1995) findings where they found that the American participants used more instances of descriptive clauses than the Japanese mothers.

\section{c. Evaluative devices:}

Table 7: Means and standard deviations for evaluative variables, comparing the native English speakers' and the EFL Kurds' English narratives

\begin{tabular}{|c|c|c|c|}
\hline & $\begin{array}{l}\text { NES } \\
(N=14)\end{array}$ & $\begin{array}{l}\text { EFLKE } \\
\qquad(N=14)\end{array}$ & $F$ \\
\hline $\begin{array}{l}\text { Mean } \\
(S D)\end{array}$ & $\begin{array}{c}\text { Mean } \\
(S D)\end{array}$ & & \\
\hline \multirow[t]{2}{*}{ Emotion } & 50.56 & 42.17 & $23.2^{\star \star}$ \\
\hline & (23.42) & $(24.29)$ & \\
\hline \multirow[t]{2}{*}{ Mental } & 38.56 & 37.67 & $3.87^{\sim}$ \\
\hline & $(40.391)$ & (30.65) & \\
\hline \multirow[t]{2}{*}{ Intensifiers } & 61.06 & 59.67 & 1.98 \\
\hline & (8.572) & $(0.45)$ & \\
\hline \multirow[t]{2}{*}{ Defeat/negative } & 54.06 & 42.67 & $7.8^{*}$ \\
\hline & (18.47) & (23.58) & \\
\hline \multirow[t]{2}{*}{ Repetition } & 166.56 & 244.67 & $5.6^{*}$ \\
\hline & (140.62) & (262.08) & \\
\hline \multirow[t]{2}{*}{ Hedges } & 34.56 & 30.67 & $27.98^{* *}$ \\
\hline & $(46.04)$ & $(40.55)$ & \\
\hline Reported speech & 35.06 & 37.67 & $88.03^{* *}$ \\
\hline
\end{tabular}




$\begin{array}{llll} & (45.34) & (30.65) & \\ \text { Delineation } & 64.56 & 49.17 & 20.7^{\star *} \\ & (3.62) & (14.39) & \\ \text { Adverbs } & 67.06 & 50.67 & 35.4^{\star *} \\ & (0.08) & (12.27) & \end{array}$

MANOVA Wilks' Lambda

The means and standard deviations for the evaluative devices in both the English native speakers' and EFL Kurdish speakers' English narratives are displayed in Table 7. Again the frequencies of the evaluative devices were conducted by using the MANOVA analysis. The analysis in Table 7 indicates that there are significant differences in the use of seven evaluative variables $(\mathrm{F}=50.26, p<.001)$. The NES contained more instances of emotions, negatives, hedges, delineation and adverbs than the EFLKE. However, there are more examples of repetition and reported speech in the EFLKE than the NES. This suggests that the EFL Kurdish participants have challenges in using most of the internal evaluative devices in their English narratives.

\subsection{Comparing EFL Kurds' Kurdish and English narratives:}

\section{a. Narrative length}

Table 8: Means and standard deviations for the narrative length in the EFL Kurds' Kurdish and English narratives

\begin{tabular}{llll}
$\begin{array}{l}\text { EFLKK } \\
(N=14)\end{array}$ & \multicolumn{1}{c}{$\begin{array}{c}\text { EFLKE } \\
(N=14)\end{array}$} & \multicolumn{1}{c}{$t$} \\
\cline { 2 - 4 } & Mean & Mean \\
& $(S D)$ & $(S D)$ & $45.503^{* * *}$ \\
\hline Clause & 104.5000 & 104.928 & \\
& $(191.71644)$ & $(170.6090)$ & \\
\hline
\end{tabular}

$\tilde{\rho}<.10 * p<.05 * * p<.01 * * * p<.001$

Table 8 presents the means and standard deviations of the narrative length in both the EFL Kurdish and English narratives. T-test was applied to gain the measurements of the number of clauses used by both groups. The statistics in Table 8 reveals that there is a significant difference in the Kurdish and English narratives told by the EFL Kurdish speakers in terms of length $(\mathrm{t}=45.503, \mathrm{p}<.001)$. On average the EFLKK used 104.5000 clauses and the EFLKE used104.928 clauses. This means that the Kurdish speakers told longer narratives in Kurdish than in English.

\section{b. Narrative Structure}

Table 9: Means and standard deviations for narrative structure variables in the Kurdish EFL narratives

\begin{tabular}{lclc}
\hline & $\begin{array}{c}\text { EFLKK } \\
(N=14)\end{array}$ & $\begin{array}{c}\text { EFLKE } \\
(N=14)\end{array}$ & $F$ \\
Mean & Mean & & \\
$(S D)$ & $(S D)$ & 51.17 & $4.9^{*}$ \\
\hline Orientation & 44.42 & $(11.56)$ & \\
& $(26.06)$ & 32.67 & $2.9^{\sim}$ \\
Appendages & 38.92 & $(37.72)$ & \\
& $(33.84)$ & 297.67 & 1.78 \\
Event & 328.42 & $(337.03)$ &
\end{tabular}




\begin{tabular}{llll} 
Duratives & 153.42 & 141.17 & $6.4^{*}$ \\
& $(128.08)$ & $(115.71)$ & \\
Evaluation & 34.42 & 32.17 & $18.09^{* *}$ \\
& $(40.20)$ & $(38.43)$ & $12.36^{* *}$ \\
\hline MANOVA Wilks' Lambda & & &
\end{tabular}

$\tilde{p}<.10 * p<.05 * * p<.01 * * * p<.001$

Table 9 presents the means and standard deviations for the narrative structure in the Kurdish and English narratives told by the Kurdish EFL speakers. MANOVA statistics was conducted to find out the measurements for five structural elements (orientation, appendages, events, duratives and evaluation). The multivariate analysis in Table 8 displays that there are significant differences within the two sets of narratives in terms of three structural elements $(\mathrm{F}=12.36, p<.01)$. The EFL speakers used more duratives and evaluation in their Kurdish narratives than the English ones. However, the EFL speakers used more orientation in their English narratives than the Kurdish ones.

\section{c. Evaluative device}

TABLE 10: Means and standard deviations for evaluative variables in the Kurdish EFL narratives

\begin{tabular}{|c|c|c|c|}
\hline & $\begin{array}{l}\mathrm{EFLKK} \\
\qquad(N=14)\end{array}$ & $\begin{array}{l}\text { EFLKE } \\
\qquad(N=14)\end{array}$ & $F$ \\
\hline $\begin{array}{l}\text { Mean } \\
(S D)\end{array}$ & $\begin{array}{c}\text { Mean } \\
(S D)\end{array}$ & & \\
\hline \multirow[t]{2}{*}{ Emotion } & 42.42 & 42.17 & $23.5^{\star *}$ \\
\hline & (28.89) & (24.29) & \\
\hline \multirow[t]{2}{*}{ Mental } & 33.42 & 37.67 & $18.9^{* *}$ \\
\hline & $(41.61)$ & (30.65) & \\
\hline \multirow[t]{2}{*}{ Intensifiers } & 47.92 & 59.67 & $98.9^{* \star *}$ \\
\hline & $(21.11)$ & $(0.45)$ & \\
\hline \multirow[t]{2}{*}{ Defeat/negative } & 50.92 & 42.67 & $25.98^{* *}$ \\
\hline & $(16.86)$ & (23.58) & \\
\hline \multirow[t]{2}{*}{ Repetition } & 262.92 & 244.67 & $43^{* *}$ \\
\hline & (282.94) & (262.08) & \\
\hline \multirow[t]{2}{*}{ Hedges } & 31.42 & 30.67 & $12.65^{\star}$ \\
\hline & (44.44) & $(40.55)$ & \\
\hline \multirow[t]{2}{*}{ Reported speech } & 31.92 & 37.67 & $12.7^{*}$ \\
\hline & (31.92) & $(30.65)$ & \\
\hline \multirow[t]{2}{*}{ Delineation } & 42.92 & 49.17 & $21.99^{* *}$ \\
\hline & (28.18) & (14.39) & \\
\hline Adverbs & & & $38.45^{\star *}$ \\
\hline
\end{tabular}

MANOVA Wilks' Lambda $28.99^{* *}$

$\tilde{p}<.10 * p<.05 * * p<.01 * * * p<.001$

Table 10 displays the results of the means and standard deviations for the evaluative devices in the EFL narratives. Again MANOVA analysis was used to gain the measurements. As it is clear form Table 10, there are significant differences in the use of all the evaluative devices (emotion, mental, intensifiers, negatives, repetition, hedges, reported speech, delineation and adverbs) in both the Kurdish and English narratives told by the EFL speakers $(\mathrm{F}=28.99, \quad p$ $<.01)$. The Kurdish narratives significantly included more instances of emotions, negatives, repetition, hedges, reported speech and delineation than the English counterparts, whereas, the English narratives contained more examples of mental, intensifiers and adverbs than the Kurdish narratives. 


\section{DISCUSSION}

Focusing on the narrative structural elements, this research explored how the EFL Kurdish speakers' stories deviate form the target language discourse norms. Supporting, Miami \& McCabe (1995) claim that the Japanese mothers used less explicit evaluation than the American mothers; the participants in this study similar to the Japanese women used less explicit evaluation than the American participants. The Kurdish speakers used more instances of orientation and durative (descriptive) clauses in their Kurdish and English narratives compared to the American speakers. This suggests that the analysis of the structural elements in the participants' stories revealed a cultural pattern of difference between the American and the EFL Kurdish speakers' style of storytelling. Generally, the American speakers told longer narratives than their Kurdish counterparts. Moreover, the American stories significantly included more evaluative devices (emotion, mental, hedges, delineation, and adverbs) than the Kurds' Kurdish and English narratives. Another pattern of difference appeared in terms of the internal evaluative device of repetition where Kurdish speakers used more repetition in their Kurdish and English narratives than the American's narratives. This finding could be explained in line with the Kurdish cultural background that is affected by the Arabic discourse. Repetition is a trait that is also noticed amongst speakers of Arabic. There is a huge volume of literature reflecting upon repetition in written discourse. Although written and spoken discourse are not directly comparable, insights derived form study of written discourse may be relevant because they are closely related (Ebrahim, 2016). Johnstone (1991: 11) argued that repetition is one of the Arabic language's rhetorical devices, and mostly its discourse is structured by repetition. Since Kurdistan is part of Iraq, it suffered different types of oppression under the Ba'ath regime. One form of oppression deprived Kurds of their rights to use the Kurdish language in constitutions, schools, universities and the media. Instead, Arabic was the official language at that time. Given that Arabic was the language that dominated schooling and the media, it is possible that the Kurdish language contains similar patterns to those found in the features of Arabic discourse, particularly in terms of repetition. As such, it is not surprising to find a rich pattern of repetition in the Kurdish style of storytelling (ibid). However, Johnstone (1991: 71) maintained that "English discourse rules (codified in rhetoric texts under "variety in word choice") encourage writers to avoid repetition". It might be for this reason that the English participants in this study preferred the use of other evaluative devises as emotion, negatives, hedges, delineation, and adverbs to repetition.

The Kurdish participants in this study were not successful in producing the correct discourse norms that goes in line with that of the target language discourse (in this case English). This might be because as Kang (2001:p. 145) said "acquiring the target language's culture-specific narrative style is one of the most important and difficult parts of second/foreign language learning". Although the Kurdish participants had undergone twelve years of English schooling and are specializing in English language (fourth year students in the Department of English), and are expected to have acquired enough knowledge about English language, yet they produced a type of discourse that does not meet the norms and rules of the target language discourse or in other words that is inappropriate to the target discourse. The discourse type produced by the Kurdish speakers is mostly a product of transference form their first language particularly in terms of repetition. More clearly, the Kurdish participants transferred rules and norms from their L1 to their L2 particularly in terms of repetition as the participants used great amounts of repetitions in their English narratives (as they did in their Kurdish narratives); a style that is not preferred or accepted in the English language discourse. This finding from this study also shed light to the difficulties that the Kurdish speakers might have in mastering other skills such as reading comprehension and writing as there is relationship between proficiency in narrative discourse and a range of literacy skills (Griffin, 1998).

To summarize, the Kurdish EFL learners of English require more awareness about the norms and rules of the target language discourse. Also instructors need to be aware about the difficulties that theses learners face in producing a correct oral discourse in the target language and need to dedicate more focus and effort to improve this area. 


\section{LIMITATION OF THE STUDY}

This study may have some limitations. The sample size is modest to draw overgeneralizations about the results. In this study 32 narratives were used for the analysis. In the future research this could be overcome and recruit more participants for the analysis. This study is pure quantitative. The insights drawn from it would have been richer if both quantitative and qualitative methods were conducted. So in order to gain deep information and knowledge about the cultural variation of the participants' narrative style and their competent problems in producing a discourse in a target language, mixed methods (quantitative and qualitative) should be used. In terms of the elicitation techniques, children wordless story was given to the learners to tell stories. This might limit them to tell natural stories.

\section{CONCLUSION}

The analysis of the frog narratives in this study advances our understanding of the crosscultural studies of narrative generally and the acquisition of the second language particularly. The comparison of the frog stories produced by the Kurdish and native English speakers revealed that there are cultural patterns of differences in the style of story telling or in other words different preferred cultural patterns in the two cultures (Kurdish and English). While structuring their narratives in Kurdish and in English, the Kurdish speakers preferred to use the structural elements of orientation and descriptive clauses. However, the preferred style of story telling by the American speakers is the frequent use of evaluation whether explicit evaluation or internal evaluative devices but repetition. In terms of the evaluative device of repetition, the Kurdish participants tended to use greater amounts of repetition in both the Kurdish and English versions in comparison to their American counterparts. This frequent use of repetition in the Kurdish participants' narratives suggests that the Kurdish participants deviate to produce a correct discourse that is in harmony with the English language discourse strategies and which is considered to be inappropriate type of discourse. This reflects the difficulties that the Kurdish participants have in acquiring the correct required norms and rules of eliciting a native like discourse.

\section{REFERENCES}

Akinci, M., Jisa, H., \& Kern, S. (2001). Influence of L1 Turkish on L2 French narratives. In L. Verhoeven \& S. Stromqvist" (Eds.), Narrative development in a multilingual context (pp. 255-276). Amsterdam: John Benjamins.

Akpinar, K. (2012). Identifying discourse patterns: A case study with Turkish foreign language learners. ELT Research Journal 2012, 1(4), 255-277.

Bakeman, R., \& Gottman, J. (1986). Observing interaction: An introduction to sequential analysis. New York: Cambridge University Press.

Bamberg, M. (1987). The acquisition of narratives: Learning to use language. Berlin: de

Gruyter.

Bamberg, M., \& Damrad-Frye, R. (1991). On the ability to provide evaluative comments: Further explorations of children's narrative competencies. Journal of Child Language 18, 689-710.

Beach, R. (1995). Constructing cultural models through response to literature. English Journal, 84, 87-95.

Bensoussan, M. (1990). EFL reading as seen through translation and discourse analysis: narrative vs. expository texts. English for Specific Purposes, 9, 49-66.

Berman, R., \& Slobin, D. I. (1994). Relating events in narrative: A crosslinguistic developmental study. Hillsdale, NJ: Lawrence Erlbaum Associates.

Blum-Kulka, S. (1993). You gotta know how to tell a story: Telling, tales, and tellers in American and Israeli narrative events at dinner. Language in Society, 22, 361-402.

Bruner, J. (1990). Acts of meaning. Cambridge, MA: Harvard University Press.

Cain, K., \& Oakhill, J. (1996). The nature of the relationship between comprehension skill and the ability to tell a story. British Journal of Developmental Psychology, 14, 187-201.

Chang, M. (2008). A cross-cultural study of Taiwanese and British University students' oral narratives. $\mathrm{PhD}$ Thesis. University of Leicester.

Ebrahim, H. (2016). Narrative analysis of the oral stories of personal experience stories told by Iraqi Kurdish and white English British English speaking women. Unpublished $\mathrm{PhD}$ Thesis. University of Leicester, UK.

Gottman, J., \& Parker, J. (1986). Conversations of friends: Speculations on affective development. New York: Cambridge University Press.

Griffin, T. (1998). Oral narrative proficiency and reading comprehension skill. Unpublished 
doctoral dissertation, Harvard Graduate School of Education, Cambridge, MA.

Heath, S. B. (1983). What no bedtime story means: Narrative skills at home and school. Language in Society, 11, 49-76.

Hemphill, L. (1999). Narrative style, social class, and response to poetry. Research in the Teaching of English, 33, 275-302.

Horiba, Y. (1990). Narrative comprehension process: A study of native and non-native readers of Japanese. The Modern Language Journal, 74, $188-202$.

Johnstone, B. (1991). Repetition in Arabic discourse: paradigms, syntagms and the ecology of language. Amsterdam/Philadelphia: John Benjamins Publishing Company.

Kang, H. (1992). Cultural interference in second language reading. International Journal of Applied Linguistics, 2, 95-119.

Kang, H. (2003). On the ability to tell good stories in another language: Analysis of Korean EFL learners' oral "Frog Story" narratives. Narrative Inquiry Journal, 13(1),127-149.

Klecan-Aker, J., \& Caraway, T. (1997). A study of relationship of storytelling ability and reading comprehension in fourth and sixth grade African-American children. European Journal of Disorders of Communication, 32, 109-125.

Kuntay, A., \& Nakamura, K. (1993, July). Evaluative strategies in monological Japanese and Turkish narratives. Paper presented at 6th International Congress for the Study of Child Language, Trieste, Italy.

Labov, W. (1972). Language in the inner city. Philadelphia: University of Pennsylvania Press. Labov, W., \& Waletzky, J. (1967). Narrative analysis: Oral versions of personal experience.In J. Helm (Ed.), Essays on the verbal and visual arts: Proceedings of the 1966 Annual Spring Meeting of the American Ethnological Society (pp. 12-44). Seattle: University of Washington Press.

Maeno, Y. (1996). Acquisition of oral narrative skills by foreign language learners of Japanese. Qualifying paper at Harvard University Graduate School of Education.

Mayer, M. (1969). Frog, where are you? New York: Dial.

McCabe, A., \& Peterson, C. (1991). Developing narrative structure. Hillsdale, NJ: Lawrence Erlbaum.
Melzi, G. (2000). Cultural variations in the construction of personal narratives: Central American and European-American Mothers' elicitation styles. Discourse Processes, 30, $153-178$.

Minami, M., \& McCabe, A. (1991). Haiku as a discourse regulation device: A stanza analysis of Japanese children's personal narratives. Language in Society, 20, 577-600.

Miami, M., \& McCabe, A. (1995). Rice balls and bear hunts: Japanese and North American family narrative patterns. Journal of Child language, 22, 423-445.

Mullen, M., \& Yi, S. (1995). The cultural context of talk about the past: Implications for the development of autobiographical memory. Cognitive Development, 10, 407-419.

Norrick, N. (2001). Discourse markers in oral narrative. Journal of Pragmatics, 33, 849-878.

Ordo'n ${ }^{\sim}$ ez, L. C. (2000). Oral bilingual proficiency of Colombian adolescents. Unpublished doctoral dissertation, Harvard University, Cambridge, MA

Pearson, B. (2001). Logic and mind in SpanishEnglish children's narratives. In L. Verhoeven \& S. Stromqvist" (Eds.), Narrative development in a multilingual context (pp. 255-276). Amsterdam: John Benjamins.

Peterson, C., \& McCabe, A. (1992). Parental styles of narrative elicitation: Effect on children's narrative structure and content. First Language, 12, 299-322.

Peterson, C., \& McCabe, A. (1983). Developmental psycholinguistics. New York: Plenum Press.

Selinker, L.\&Gass, S. (eds.) (1991). Language transfer in language learning. John BenjaminB.V.

Shiro, M. (1998). Getting the story across : A discourse analysis approach to evaluative stance in Venezuelan children's narratives. Unpublished doctoral dissertation, Harvard University Graduate School of Education, Cambridge, MA

Uccelli, P. (1997). Beyond chronicity: temporality and evaluation in Andean Spanish-speaking children's narratives. Unpublished qualifying paper at Harvard Graduate School of Education, Cambridge, MA. 
يوخته

ئه ثه كولينه ل دوف ريّبازا ( Labov\& Waletzky, 1967 , Peterson \&McCabe) بو ئلافيّن

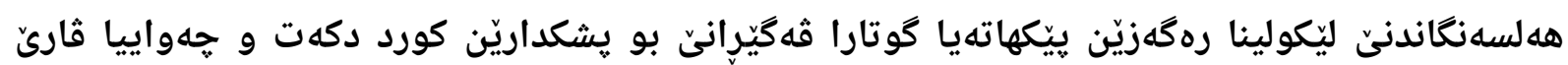

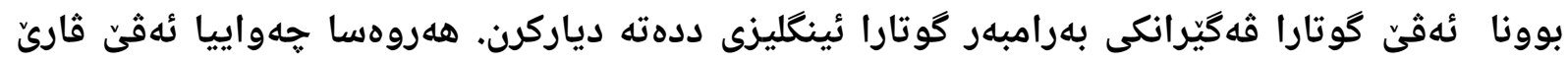

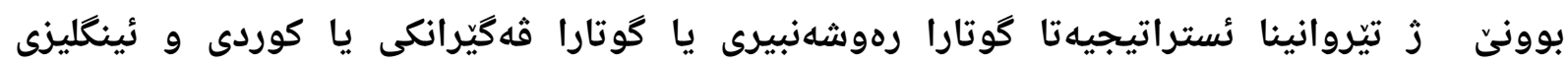
كهنكُه شهدكهت. ثهكولهرى رومانيّن (بهق)ى شروقه كرينه كو ز لايّى يشكداريّن كوردثه ب ههردوو زمانيّن كوردى و

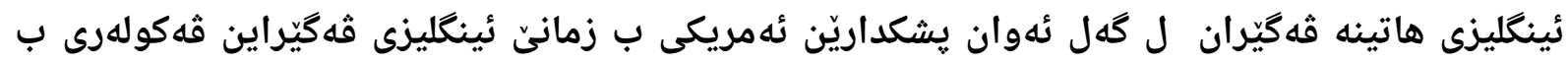

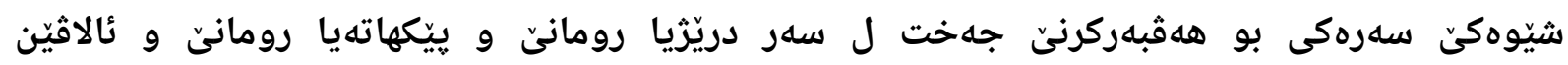
هه لسهنغاندني د هلى سئ روماناندا كريه.

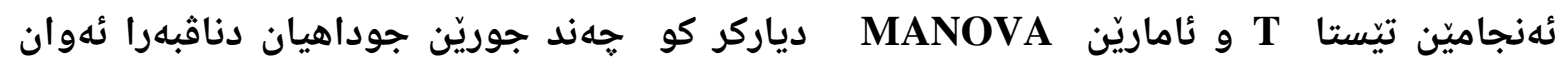

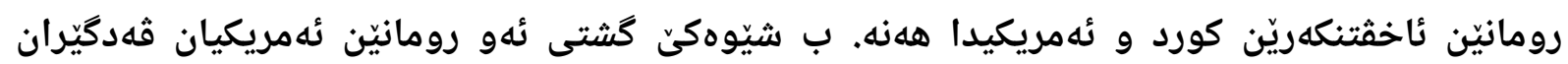

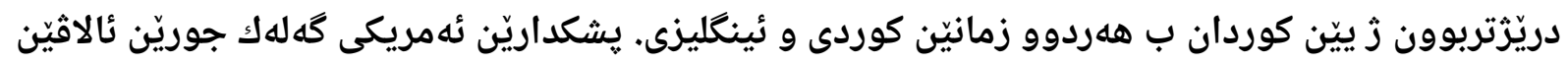

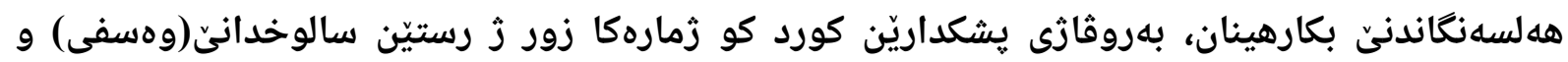

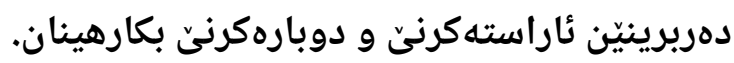

الخلاصة

هذا المقال استخدم منهج (Peterson \&McCabe, 1991) و (Labov \& Waletzky 1967) للادوات

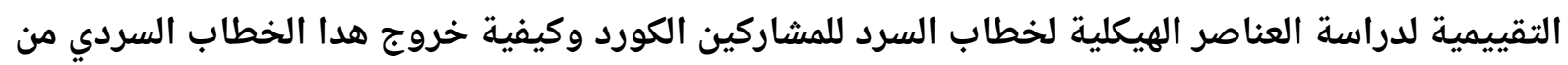
مسار الخطاب الانكليزي وكيفية مناقشة هدا الخروج من منظور استراتيجيات الخطاب الثقافي للحوار السردي الكوردي والانكليزي. هده الدراسةقامت بتحليل روايات الضفدع التي سردها المشاركين الكورد

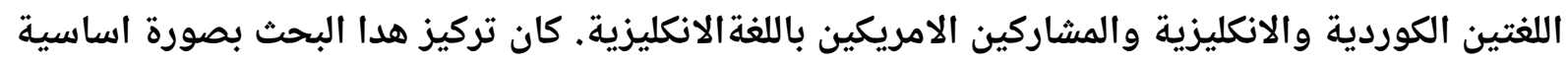

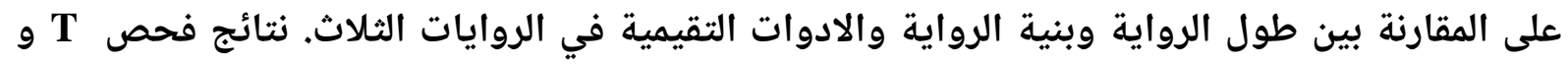
احصائيات MANOVA بينت ان هناك تباين كبير بين الروالت التي سردها الكورد ولامريكين. بصورة عامة الروايات التي سردها الامريكيون كانت اطول من تلك التي سردها الكوردباللغتين الكوردية والانكليزية. المشاركين الامريكين استخدموا عدد وافر من الادوات التقيمية على خلاف المشاركين الكورد اللدين استخدموا عدد كبير من الجمل الوصفية والعبارات التوجيهية والتكرار. 